\title{
EFFECT OF HARVEST INTERVALS ON THE CHEMICAL COMPOSITION AND NUTRITIVE VALUE OF NAPIER GRASS (Pennisetum purpureum Schum.) SILAGES FOR GOATS
}

\author{
H. Yokota ${ }^{1}$ T. Okajima and M. Ohshima \\ Laboratory of Grassland Science, The Farm, School of Agricultural \\ Science, Nagoya University, Togo, Aichi 470-01, Japan
}

\begin{abstract}
Summary
Chemical composition and nutritive values of napier grass (Pennisetum purpureum Schum.) silages subjected to two cutting intervals were studies; 1st harvest in July (A), and 2nd (B) and 1st (C) harvests in November. Each forage was ensiled with $4 \%$ molasses in plastic bags and stored for 5 or 9 months. A feeding experiment with castrated goats was conducted from April to June of the following year. Dry matter (DM) and crude protein (CP) content of the harvests varied from 9.5 to $22.8 \%$ and 6.6 to $13.6 \%$ of DM, respectively. The dry matter content of the silages fed to the goats were 13.0 to $24.2 \%$, because some effluent was removed from each silage before the feeding trial. The $\mathrm{pH}$ values of the silages were between 4.03 and 4.29 . Goats were given sufficient silage to meet maintenance nitrogen requirements from napier grass silage. Silage $\mathrm{C}$ was not completely consumed, and the silage had low digestibilities of DM, CP, hemicellulose and cellulose. Nitrogen balance was slightly positive for goats consuming silage $\mathrm{B}$ and was negative for goats consuming silages $\mathrm{A}$ and $\mathrm{C}$. Nitrogen utilization was discussed in terms of ruminal $\mathrm{NH}_{3}-\mathrm{N}$ and volatile fatty acid concentration in the rumen fluids. It is concluded that goats could not maintain $\mathrm{N}$-equilibrium not only when a younger forage was consumed at a level of $\mathrm{N}$ requirement by a restricted feeding, but also when an older forage could not be consumed enough for $\mathrm{N}$ requirement because of feed intake limitation.
\end{abstract}

(Key Words: Napier Grass, Pennisetum purpureum Schum., Silage, NDF, ADF, Digestibility, Goats)

\section{Introduction}

Seasonal rainfall in most tropical areas produces a variable supply of crops which should be conserved for use during shortage of feed supply. Silage making is a method of forage preservation for animal production. Quality of silages from temperate forages is based on low $\mathrm{pH}$ value and high lactic acid content. Catchpoole and Henzell (1971) stated that silage from a number of tropical herbage plants was stable against anaerobic decomposition, but its chemical characteristics was different from lactate-type silages of temperate forages. Yokota et al. (1991) reported napier grass (Pennisetum purpureum Schum.) with molasses produced a lactate-type silage, which was high in lactic acid content and low in $\mathrm{pH}$ value, ammonia nitrogen, and acetic and butyric acid contents. Moreover, napier grass ensiled without the additive was low in lactic acid and high in $\mathrm{pH}$ value, ammonia

\footnotetext{
${ }^{1}$ Address reprint requests to Dr. H. Yokota, Laboratory of Grassland Science, The Farm, School of Agricultural Science, Nagoya University, Togo, Aichi 470-01, Japan.

Received November 29, 1993

Accepted July 29, 1994
}

nitrogen and VFA. Yokota et al. (1992) further indicated that goats fed only napier grass ensiled with molasses could maintain their body weight and retained positive nitrogen balance.

Lignin is a chemical component in forage cell walls, increases with the development of the grass and is most commonly associated with reduced digestibility of fibre. In tropical grasses high temperatures during growth reduce DM digestibility, because of increased amounts of cell wall and its lignification, as well as promoting stem development (Ford et al., 1979). Jung (1989) described that core lignin is bound to hemicellulose but not to cellulose, and hypothesized that hemicellulose digestion should be more inhibited by lignin than cellulose digestion.

The present study investigated changes in forage constituents associated harvest intervals of napier grass, the chemical composition of silages produced from them, and their utilization for goats.

\section{Materials and Methods}

Napier grass (Merkeron) was harvested on three occasions in central Japan. In this region napier grass begins to grow from the beginning of May 
and the aboveground materials dies from frost after December. Primary growth was harvested on July 5 (A) and on November 14 (C) and the regrowth was harvested on November 14 (B) 1988. After cutting into about $2 \mathrm{~cm}$ lengths, the grass was mixed with $4 \%$ molasses at fresh matter basis and ensiled in polyethylene bags of $15 \mathrm{~kg}$ capacity. The bags were stored in a room with an ambient temperature of 5 to $30^{\circ} \mathrm{C}$ for 5 or 9 months until animal feeding studies were conducted from April to June, 1989. Bags were opened one by one when feeding studies were started. At opening of the bag silage effluents were removed. Amounts of the silage to be fed to individual goats at each feeding time were packed tightly again and stored in a refrigerator $\left(4^{\circ} \mathrm{C}\right)$. Repacked silages were used at least for 10 days for feeding trials.

\section{Feeding trials}

Three Japanese pygmy castrated adult male goats weighing between 12 to $14 \mathrm{~kg}$ were used. The feeding trial was carried out using a $3 \times 3$ Latin square design. The goats were kept individually in metabolism crates, and offered the silages at a maintenance level of nitrogen calculated from NRC standards (NRC, 1981). Silages were offered in two equal meals at 09:00 and 17:00. Two grams of $\mathrm{NaCl}$ and $10 \mathrm{~g}$ of $\mathrm{CaHPO}_{4}$ were given with the morning ration. The goats were offered the ration for 13 days and all faeces and urine were collected for five days from 7 th to 12 th day. Ruminal fluid and blood were taken on the 13th day before and four hours after the morning feeding. The rumen fluid $(50 \mathrm{ml})$ was sucked by stomach tube, filtered immediately through two folds of cheese cloth, and $\mathrm{HgCl}_{2}$ added to stop further fermentation. The jugular venous blood samples were collected in heparinized tubes. Plasma was obtained immediately and stored at $-15^{\circ} \mathrm{C}$ for urea determination.

\section{Chemical analyses}

The toluene dry matter and nitrogen contents were determined on fresh silage samples. Other chemical components of fresh grasses and faeces were determined on samples dried in a forced air oven at $60^{\circ} \mathrm{C}$ for 48 hours. Nitrogen and ash were analysed according to AOAC (1984) procedure. Neutral detergent fibre (NDF) was determined by the method of Van Soest and Wine (1967), and acid detergent fibre (ADF) and acid detergent lignin (ADL) by the method of Van Soest (196 3 ). Hemicellulose and cellulose were calculated as NDF minus $\mathrm{ADF}$, and $\mathrm{ADF}$ minus ADL, respectively. Chemical quality of silages was determined on cold water extracts. The extracts and rumen fluid samples were analysed as described in detail by Ohshima et al. (1991). The pH value was determined with electrode $\mathrm{pH}$ meter, and total concentration of VFA and $\mathrm{NH}_{3}-\mathrm{N}$ by steam distillation. Individual VFAs were gaschromatographycally determined on the distillates of the samples (Ohshima et al., 1991). Lactic acid in silage samples was determined colorimetrically (Barnett, 1951). Blood urea nitrogen (BUN) was measured using a commercial kit (Chugai Pharmaceutical Ltd. Tokyo).

Data were subjected to analysis of variance, and statistical significance among treatment means was determined by Duncan's multiple range test.

\section{Results}

Sward length of the grasses at harvest were 212, 294 and $366 \mathrm{~cm}$ for grass A, B and C, respectively. At opening of silages mean spoilage was calculated to $11.4,2.7$ and $0 \%$ of silages $\mathrm{A}$, $\mathrm{B}$ and $\mathrm{C}$, respectively.

Chemical composition of the napier grass and the corresponding silages are shown in table 1 . Fresh grass $\mathrm{C}$ was lower in protein and ash content, but higher in cellulose and ADL content than samples A and B. Hemicellulose contents of silages decreased during ensilage; the maximum in silage B $(38 \%)$ and the minimum in $\mathrm{C}(14 \%)$ on a dry matter basis.

The $\mathrm{pH}$ values of silages were from 4.03 to 4.29 (table 2). In spite of the highest lactic acid content, silage $\mathrm{A}$ showed the highest $\mathrm{pH}$ value due to higher concentrations of $\mathrm{NH}_{3}-\mathrm{N}$ and butyric acid.

Results of the feeding trial with goats are shown in table 3 . Silage $\mathrm{C}$ was consumed only $67 \%$ of nitrogen requirement for maintenance, although dry matter (DM) intake was the highest among the three treatments. Organic matter (OM) intake was proportional to DM intake. Digestibilities of silage $C$ in all the nutrients examined here were lower than silages $\mathrm{A}$ and $\mathrm{B}$.

Characteristics of rumen fluids and blood urea nitrogen are shown in table 4. Ruminal pH was almost neutral before feeding of the silage and 
was statistically $(\mathrm{p}<0.05)$ decreased nearly to 6.6 after feeding irrespective of rations. The proportion of acetate decreased and those of propionate and butyrate increased after feeding. Ruminal $\mathrm{NH}_{3}-\mathrm{N}$ concentration of goats fed silages $\mathrm{A}$ and
$B$ were increased to more than $20 \mathrm{mg} / \mathrm{dl}$. Blood plasma urea $\mathrm{N}$ concentration was hardly changed after 4 hours after feeding within each ration. The highest value was shown in goats consuming silage A.

TABLE 1. CHEMICAL COMPOSITION OF NAPIER FRESH GRASS AND THEIR SILAGES ${ }^{1)}$

\begin{tabular}{lccr}
\hline & $\mathrm{A}^{2)}$ & \multicolumn{1}{c}{$\mathrm{B}^{3)}$} & $\mathrm{C}^{4)}$ \\
\hline Fresh & & & \\
$\quad$ Dry matter & 9.5 & 11.2 & 22.8 \\
Crude protein (\%DM) & 13.6 & 12.6 & 6.6 \\
Hemicellulose (\%DM) & 23.0 & 29.1 & 26.1 \\
Cellulose (\%DM) & 33.2 & 31.2 & 39.1 \\
Acid detergent lignin (\%DM) & 4.6 & 3.5 & 9.1 \\
Ash (\%DM) & 16.0 & 17.6 & 9.8 \\
Silages & & & 3 \\
Numbers of bags & 6 & 5 & $24.1 \pm 0.4$ \\
Dry matter & $13.0 \pm 0.3$ & $15.9 \pm 0.3$ & $6.8 \pm 0.1$ \\
Crude protein (\%DM) & $12.0 \pm 0.3$ & $18.1 \pm 0.3$ & $22.5 \pm 0.8$ \\
Hemicellulose (\%DM) & $18.1 \pm 0.4$ & $29.0 \pm 0.3$ & $35.9 \pm 0.8$ \\
Cellulose (\%DM) & $33.2 \pm 0.1$ & $3.2 \pm 0.1$ & $6.5 \pm 0.5$ \\
Acid detergent lignin (\%DM) & $3.7 \pm 0.1$ & $18.6 \pm 0.2$ & $12.0 \pm 0.2$ \\
Ash (\%DM) & $16.7 \pm 0.3$ & & \\
\hline
\end{tabular}

Mean \pm SEM

1) All the silages were prepared by adding $4 \%$ molasses on fresh matter basis.

2) Ist harvest on July 5, 1988.

3) 2nd harvest on November 14, 1988.

4) Ist harvest on November 14, 1988.

TABLE 2. CHEMICAL QUALITY OF THE SILAGES ${ }^{1)}$

\begin{tabular}{lccc}
\hline Silage & $\mathrm{A}^{2)}$ & $\mathrm{B}^{3)}$ & $\mathrm{C}^{4)}$ \\
Numbers of bags & 6 & 5 & 3 \\
\hline Dry matter (\%) & $13.00 \pm 0.23^{\mathrm{A} 5)}$ & $15.89 \pm 0.25^{\mathrm{B}}$ & $24.15 \pm 0.40^{\mathrm{C}}$ \\
pH & $4.29 \pm 0.21$ & $4.03 \pm 0.03$ & $4.13 \pm 0.02$ \\
Total acid (\%DM) & $10.32 \pm 1.05^{\mathrm{A}}$ & $9.45 \pm 0.40^{\mathrm{A}}$ & $5.08 \pm 0.44^{\mathrm{B}}$ \\
$\quad$ Lactic acid (\%DM) & $7.69 \pm 1.23$ & $7.50 \pm 0.21$ & $4.07 \pm 0.41$ \\
Acetic acid (\%DM) & $2.21 \pm 0.25^{\mathrm{A}}$ & $1.79 \pm 0.25^{\mathrm{A}}$ & $0.99 \pm 0.02^{\mathrm{B}}$ \\
$\quad$ Propionic acid (\%DM) & $0.21 \pm 0.18$ & $0.08 \pm 0.07$ & $0.13 \pm 0.03$ \\
Butyric acid (\%DM) & $0.14 \pm 0.09$ & $0.07 \pm 0.06$ & $0.06 \pm 0.03$ \\
Ammonia N/total N (\%) & $14.35 \pm 3.45$ & $6.67 \pm 0.65$ & $8.18 \pm 2.32$ \\
\hline
\end{tabular}

Mean \pm SEM.

1) All the silages were prepared by adding $4 \%$ molasses on fresh matter basis.

2) 1st harvest on July 5, 1988.

3) 2nd harvest on November 14, 1988.

4) Ist harvest on November 14, 1988.

5) Different superscripts within the same row differ at $\mathrm{p}<0.05$. 
YOKOTA ET AL.

TABLE 3. DIGESTIBILITY OF SOME NUTRIENTS AND NITROGEN BALANCES IN GOATS FED NAPIER GRASS SILAGES

\begin{tabular}{lccc}
\hline Silage & $\mathrm{A}^{\mathrm{1}}$ & $\mathrm{B}^{2)}$ & $\mathrm{C}^{3)}$ \\
\hline Liveweight of goats $(\mathrm{kg})$ & $12.8 \pm 0.2$ & $13.2 \pm 0.6$ & $13.0 \pm 0.4$ \\
Intake (g/5 days) & & & \\
$\quad$ Dry matter & 1,151 & 1,252 & 1,468 \\
Organic matter & 949 & 1,016 & 1,299 \\
Crude protein & 138 & 144 & 100 \\
Digestibility (\%) & & & \\
Dry matter & $\left.69.2 \pm 0.9^{\mathrm{A}}\right)$ & $68.9 \pm 1.4^{\mathrm{A}}$ & $49.4 \pm 3.8^{\mathrm{B}}$ \\
Organic matter & $70.3 \pm 0.6^{\mathrm{A}}$ & $71.9 \pm 0.8^{\mathrm{A}}$ & $48.6 \pm 4.2^{\mathrm{B}}$ \\
Crude protein & $68.9 \pm 0.7^{\mathrm{A}}$ & $67.1 \pm 2.1^{\mathrm{A}}$ & $40.7 \pm 2.0^{\mathrm{B}}$ \\
Hemicellulose & $68.1 \pm 3.0^{\mathrm{A}}$ & $68.6 \pm 2.7^{\mathrm{A}}$ & $44.2 \pm 6.0^{\mathrm{B}}$ \\
Cellulose & $79.6 \pm 0.5^{\mathrm{A}}$ & $81.1 \pm 1.3^{\mathrm{A}}$ & $56.4 \pm 3.8^{\mathrm{B}}$ \\
Nitrogen balance (g/5 days) & & & \\
Intake N & 22.1 & 23.0 & 16.0 \\
Fecal N & $7.0 \pm 0.1^{\mathrm{A}}$ & $7.3 \pm 0.3^{\mathrm{A}}$ & $9.0 \pm 0.4^{\mathrm{B}}$ \\
Urinary N & $17.7 \pm 1.8$ & $15.2 \pm 0.3$ & $12.3 \pm 1.1$ \\
Retained N & $-2.6 \pm 1.6^{\mathrm{A}}$ & $0.5 \pm 0.5^{\mathrm{A}}$ & $-5.3 \pm 0.7^{\mathrm{B}}$ \\
\hline
\end{tabular}

Mean \pm SEM. $(\mathrm{n}=3)$.

1) 1st harvest on July $5,1988$.

2) 2nd harvest on November 14, 1988.

3) Ist harvest on November 14, 1988.

4) Different superscripts within the same row differ at $p<0.05$.

TABLE 4. CHARACTERISTICS OF RUMEN FLUIDS AND BLOOD PLASMA OF GOATS FED THE NAPIER GRASS SILAGE

\begin{tabular}{|c|c|c|c|c|}
\hline & \multirow{2}{*}{$\begin{array}{c}\text { Time after } \\
\text { feeding (hours) }\end{array}$} & \multicolumn{3}{|c|}{ Silage } \\
\hline & & $A^{1)}$ & $\mathrm{B}^{2)}$ & $\mathrm{C}^{3)}$ \\
\hline \multicolumn{5}{|l|}{ Rumen fluid } \\
\hline \multirow{2}{*}{$\mathrm{pH}$} & 0 & $6.92 \pm 0.05$ & $6.94 \pm 0.06$ & $7.10 \pm 0.08$ \\
\hline & 4 & $6.66 \pm 0.07$ & $6.59 \pm 0.06$ & $6.62 \pm 0.05$ \\
\hline \multirow[t]{2}{*}{ Total VFA (mmole/dl) } & 0 & $5.31 \pm 0.43$ & $4.67 \pm 0.57$ & $6.72 \pm 0.97$ \\
\hline & 4 & $8.25 \pm 0.32$ & $7.76 \pm 0.32$ & $6.01 \pm 0.97$ \\
\hline \multirow[t]{2}{*}{ Acetate (\%) } & 0 & $77.9 \pm 3.2$ & $82.4 \pm 0.6$ & $74.8 \pm 2.7$ \\
\hline & 4 & $69.3 \pm 3.5$ & $72.6 \pm 1.2$ & $66.9 \pm 1.2$ \\
\hline \multirow[t]{2}{*}{ Propionate (\%) } & 0 & $16.4 \pm 2.1$ & $12.7 \pm 0.7$ & $19.0 \pm 1.9$ \\
\hline & 4 & $21.6 \pm 3.0$ & $17.3 \pm 0.9$ & $21.9 \pm 1.1$ \\
\hline \multirow[t]{2}{*}{ Butyrate (\%) } & 0 & $4.4 \pm 0.9$ & $4.0 \pm 0.3$ & $5.5 \pm 0.9$ \\
\hline & 4 & $7.3 \pm 0.9$ & $7.9 \pm 0.9$ & $10.0 \pm 0.3$ \\
\hline \multirow[t]{2}{*}{ Ammonia $\mathrm{N}(\mathrm{mg} / \mathrm{dl})$} & 0 & $7.3 \pm 1.3$ & $6.1 \pm 1.2$ & $10.8 \pm 1.2$ \\
\hline & 4 & $23.8 \pm 0.6^{\mathrm{A}^{4)}}$ & $21.5 \pm 1.2^{\mathrm{A}}$ & $13.1 \pm 1.5^{\mathrm{B}}$ \\
\hline \multicolumn{5}{|l|}{ Blood plasma } \\
\hline \multirow[t]{2}{*}{ Urea-Nitrogen $(\mathrm{mg} / \mathrm{dl})$} & 0 & $13.9 \pm 2.0$ & $8.0 \pm 1.1$ & $10.1 \pm 1.5$ \\
\hline & 4 & $13.5 \pm 3.1$ & $7.0 \pm 1.3$ & $12.0 \pm 1.5$ \\
\hline
\end{tabular}

Mean $\pm \operatorname{SEM}(\mathrm{n}=3)$.

1) 1st harvest on July 5, 1988.

2) 2nd harvest on November 14, 1988.

3) 1st harvest on November 14, 1988.

4) Different superscripts within the same row differ at $\mathrm{p}<0.05$. 


\section{Discussion}

Silage A was lower in decreasing rate of hemicellulose content during ensilage $(21.3 \%$ ) than silage B $(37.8 \%)$. This result might mean constituents of hemicellulose harvested in July have a little higher resistance ability to decompose during ensilage. These suggest constituents and/or structure of hemicellulose might be changed by some factors such as seasonal temperature or precipitation. Including silage $\mathrm{C}$ decreasing rates of hemicellulose during ensilage decreased with the increase of the lignin content in fresh materials. This result coincided with the report of Jung (1989) which showed lignin was bound to hemicellulose, but not to cellulose.

In the present experiment goats were offered silages at a level of $\mathrm{N}$ requirement for maintenance. As a result, silages $\mathrm{A}$ and $\mathrm{B}$ were given on a restricted feeding at a level of 1.64 and $1.79 \%$ $\mathrm{DM} /$ liveweight $(\mathrm{LW})$, and silage $\mathrm{C}$ was eaten $\mathrm{ad}$ libitum at a level of $2.1 \% \mathrm{DM} / \mathrm{LW}$. At an ad libitum feeding of a napier grass silage, growing goats ate 3.1 to $4.1 \% \mathrm{DM} / \mathrm{LW}$ (Yokota et al., 1994). Difference between goats fed silage $A$ and silage $\mathrm{B}$ was the quantity of organic matter intake; goats fed silage A ate $6.6 \%$ less than goats fed silage B. Digestibility of some nutrients was almost the same between silage A and B. If goats fed silage $\mathrm{A}$ had offered the same quantity of organic matter as goats fed silage $\mathrm{B}, \mathrm{N}$ retention may have improved.

Satter and Slyter (1974) reported that $\mathrm{NH}_{3}-\mathrm{N}$ concentration of rumen fluid was the optimum at 5 to $8 \mathrm{mg} / \mathrm{dl}$ for the maximum microbial growth. Krebs and Leng (1984), however, indicated that minimum $\mathrm{NH}_{3}-\mathrm{N}$ concentration for optimum intake of low digestible forages was about 20 $\mathrm{mg} / \mathrm{dl}$. Slyter et al. (1979) also described that nitrogen retention increased until ruminal $\mathrm{NH}_{3}-\mathrm{N}$ concentration increased to $4.5 \mathrm{mg} / \mathrm{dl}$ after ruminal urea infusion in steers, and the retention increased further when ruminal $\mathrm{NH}_{3}-\mathrm{N}$ concentration increased to $22.5 \mathrm{mg} / \mathrm{dl}$. In the present experiments $\mathrm{NH}_{3}$ $\mathrm{N}$ concentration in the rumen fluid of goats fed the lower digestible silage $\mathrm{C}$ was $13.1 \mathrm{mg} / \mathrm{dl}$ at four hours after feeding. However, $\mathrm{NH}_{3}-\mathrm{N}$ concentration of goats fed the higher digestible silages $\mathrm{A}$ and $\mathrm{B}$ were 23.8 and $21.5 \mathrm{mg} / \mathrm{dl}$, respectively. According to Yokota et al. (1995) ruminal $\mathrm{NH}_{3} \mathrm{~N}$ concentration increased rapidly for two hours after feeding, and then gradually decreased to a little higher levels at 8 hours after feeding than that of pre-feeding level in goats fed napier grass silage. As silage $\mathrm{C}$ was a low digestible forage, improvement of $\mathrm{N}$ utilization of the silage might need an additional $\mathrm{N}$ after Krebs and Leng (1984). A positive relationships between concentrations of ruminal $\mathrm{NH}_{3}-\mathrm{N}$ and plasma urea- $\mathrm{N}$ (Vercoe, 1969), and plasma urea concentration and urea entry rate into the rumen (Kennedy, 1980) have been demonstrated. In the present experiment, however, no relationship $(\mathrm{r}=-0.060)$ between concentrations of ruminal $\mathrm{NH}_{3}-\mathrm{N}$ and plasma urea- $\mathrm{N}$ was found. Ruminal $\mathrm{NH}_{3}-\mathrm{N}$ concentration was significantly $(\mathrm{p}<0.05)$ related to urinary $\mathrm{N}$ excretion. Blood urea concentration of goats fed silage $\mathrm{B}$ was the lowest among goats fed 3 kinds of silages, although the ruminal $\mathrm{NH}_{3}-\mathrm{N}$ concentration was at a high level. This suggest goats fed silage B could utilize $\mathrm{NH}_{3}-\mathrm{N}$ in the rumen and showed positive $\mathrm{N}$ balance. Recently $\mathrm{N}$ supplementation is often applied to the lower quality forages for ruminant production, and often excessively increases $\mathrm{NH}_{3}-\mathrm{N}$ concentration in ruminal fluids and might increase urinary $\mathrm{N}$ which means losses of $\mathrm{N}$ resources.

Non-protein $\mathrm{N}$ is not necessarily utilized by ruminants as a nitrogen source unless readily available energy material is present in the rumen during fermentation and digestion (Benjamin et al., 1992). In the present experiment ruminal total VFA concentration of goats fed the lowest digestible silage $(\mathrm{C})$ was almost the same level between 0 and 4 hours after feeding. However, goats fed the higher digestible napier grass silages (A and B) showed 1.5 times higher concentration of total VFA at 4 hours after feeding than at pre-feeding. These results suggest that ruminal $\mathrm{NH}_{3}-\mathrm{N}$ might be utilized in the latter silages more than the former silages, because synchronization between $\mathrm{N}$ release and energy availability is necessary for better utilization of nutrients in the rumen (ARC, 1980). Obara and Shimbayashi (1980) suggested that non-protein $\mathrm{N}$ utilization may be influenced not only by the concentration but also by the quality of carbohydrate and other nutrients in the rumen at the same time. Further studies are necessary on energy supplementation to napier grass silages to promote utilization of forages in tropical and sub-tropical areas. 


\section{YOKOTA ET AL.}

\section{Acknowledgements}

The authors thank to Messrs. T. Harada, M. Tsuge, T. Nagatomo and $\mathrm{N}$. Inagaki for their technical assistance for cultivation of napier grass and silage making, and to Ms. K. Goto for chemical analysis.

\section{Literature Cited}

AOAC. 1984. Official methods of analysis (14th ed.). Association of Official Analytical Chemists, Washington, D. C.

Agricultural Research Council. 1980. The Nutrient Requirement of Ruminant Livestock. Farnham Royal: Commonwealth Agricultural Bureau.

Barnett, A. J. G. 1951. The colorimetric determination of lactic acid in silage. Biochem. J. 49:527-529.

Benjamin, R. W., E. Oren, E. Katz and K. Becker. 1992. The apparent digestibility of Atriplex barclayana and its effect on nitrogen balance in sheep. Anim. Prod. 54:259-264.

Catchpoole, V. R. and E. F. Henzell. 1971. Silage and silage making from tropical herbage species. Herbage Abstr. 41:213-221.

Ford, C. W., I. M. Morrison and J. R. Wilson. 1979. Temperature effects on lignin, hemicellulose and cellulose in tropical and temperature grasses. Aust. J. Agric. Res. 30:621-633.

Jung, H. G. 1989. Forage lignins and their effects on fiber digestibility. Agron. J. 81:33-38.

Krebs, G. and R. A. Leng. 1984. The effect of supplementation with molasses/urea blocks on ruminal digestion. Proc. Aust. Soc. Anim. Prod. 15:704.

NRC. 1981. Nutrient requirement of goats: Angora, dairy, and meat goats in temperate and tropical countries. National Academy Press, Washington. D.C.
Obara, Y. and K. Shimbayashi. 1980. The appearance of re-cycled urea in the digestive tract of goats during the final third of a once daily feeding of a low-protein ration. Br. J. Nutr. 44:295-305.

Ohshima, M., K. Miyase, N. Nishino and H. Yokota. 1991. Ruminal acid concentrations of goats fed hays and silages prepared from Italian ryegrass and its pressed cake. Asian-Australasian J. Anim. Sci. 4: 59-65.

Satter, L. D. and L. L. Slyter. 1974. Effect ammonia concentration on rumen microbial protein production in vitro. Br. J. Nutr. 32:199-208.

Slyter, L. L., L. D. Satter and D. A. Dinius. 1979. Effect of ruminal ammonia concentraton on nitrogen utilization by steers. J. Anim. Sci. 48:906-912.

Van Soest, P. J. 1963. Use of detergents in the analysis of fibrous feeds. II. A rapid method for the determination of fiber and lignin. J.A.O.A.C. 46:829835.

Van Soest, P. J. and R. H. Wine. 1967. Use of detergents in the analysis of fibrous feeds. IX. Determination of plant cell-wall constituents. J.A.O.A.C. 50:50-55.

Vercoe, J. E. 1969. The transfer of nitrogen from the blood to the rumen in cattle. Aust. J. Agric. Res. 20:191-197.

Yokota, H., T. Okajima and M. Ohshima. 1991. Effect of environmental temperature and addition of molasses on the quality of napier grass (Pennisetum purpureum Schum.) silage. Asian-Australasian J. Anim. Sci. 4:377-382

Yokota, H., T. Okajima and M. Ohshima. 1992. Nutritive value of napier grass (Pennisetum purpureum Schum.) silage ensiled with molasses by goats. Asian-Australasian J. Anim. Sci. 5:33-37.

Yokota, H., T. Okajima and M. Ohshima. 1995. The effect of wheat-mill-run addition to napier grass (Pennisetum purpureum Schum.) at ensiling on its nutritive value for goats. J. Japan. Grassl. Sci. 40 (in press) 